AFRICAN

\title{
From humanitarianism to trade promotion: the changing emphasis of Japanese development co-operation to Africa
}

by Shoko Yamada*

Graduate School of International Development, Nagoya University

Nagoya, Japan

\begin{abstract}
It is only in the last 20 years that Africa has become a region to which Japanese official development assistance (ODA) personnel have attached significance. Until then, in its development aid programs, Japan long focused on Asian countries with which it has strong relationships, not only in terms of history and culture, but also economically and politically. As Japan became the top bi-lateral donor in 1989, it started to explore its unique approach of leadership in international development and launched the Tokyo International Conference on African Development (TICAD), which has convened every five years since 1993. The latest conference (TICAD V) was held in 2013. In this article, the author examines the diverse interests of stakeholders involved in the discourse on aid to Africa from business, diplomatic, and humanitarian perspectives. The background of these different motives will be analysed through published and unpublished documents, supplemented by interviews with people involved in the planning and implementation of TICADs, particularly those in 2008 and 2013. The paper find that while Japanese aid to Africa will likely be sustained at the current levels, the focus is likely to shift more toward pragmatic partnerships between African states and Japan economically and diplomatically.
\end{abstract}

* Shoko Yamada is a professor at the Graduate School of International Development at Nagoya University in Japan. 


\section{Introduction}

It is only in the last 20 years that Africa has become a region to which Japanese ODA personnel have attached significance. Until then, in its development aid programs, Japan long focused on Asian countries with which it has strong relationships, not only in terms of history and culture, but also economically and politically. As Japan became the top bi-lateral donor in 1989, it started to explore its unique approach of leadership in international development and launched the Tokyo International Conference on African Development (TICAD), which has convened every five years since 1993. The latest conference (TICAD V) was held in 2013.

In this article, I will examine the diverse interests of stakeholders involved in the discourse on aid to Africa from business, diplomatic, and humanitarian perspectives. The background of these different motives will be analysed through published and unpublished documents, supplemented by interviews with people involved in the planning and implementation of TICADs, particularly those in 2008 and 2013.

Due to the geographic distance, and hence less apparent historical connections than those between Europe and Africa, increasing Japan's commitment to Africa has always been a matter of domestic debate. At the same time, the change of macroeconomic and diplomatic contexts has influenced the domestic atmosphere. The recent increase of attention to Africa is largely motivated by the steady growth of African economies and rivalry with China, which is increasing its political and economic presence in Africa. The supporters of humanitarian causes are facing the increasingly difficult task of mainstreaming their arguments, while aid to Africa, in general, has increased its share in the total amount of Japanese ODA.

\section{Historical Development of Japanese ODA to Africa and TICADs}

The history of Japanese aid provision after World War II can be traced back to as early as 1954 when Japan joined the Colombo Plan. It started as a form of compensation for the damage caused by Japanese occupation during the war. Therefore, in its earlier stage, the majority of ODA was directed to Asian countries. In the 1980 s, the Japanese economy prospered on an unprecedented scale and the 


\section{AFRICAN \\ EAST-ASIAN \\ AFFAIRS \\ THE CHINA MONITOR}

country became one of top economic powers of the world. At the same time, Japan and its companies were criticised as "economic animals", selfishly pursuing their own economic interests while neglecting the impact of their economic activities on the people of other countries and, as one of the most economically powerful nations, for not taking due responsibility for the welfare of the world. In response to this international pressure and to its internal drives for a leadership role in the world, the Japanese government rapidly increased the amount of ODA. The diversification of ODA resources to regions other than Asia also started around this time (Figure 1).

The TICAD was launched in 1993. TICAD is the conference which Japan co-hosted with UN Office of the Special Advisor on Africa (OSSA) and UNDP, African Union and the World Bank every five year, with the purpose of promoting high-level policy dialogue between African leaders and development partners. It is not a place to

\section{Figure 1: Trend of Japanese Bilateral ODA by Region}

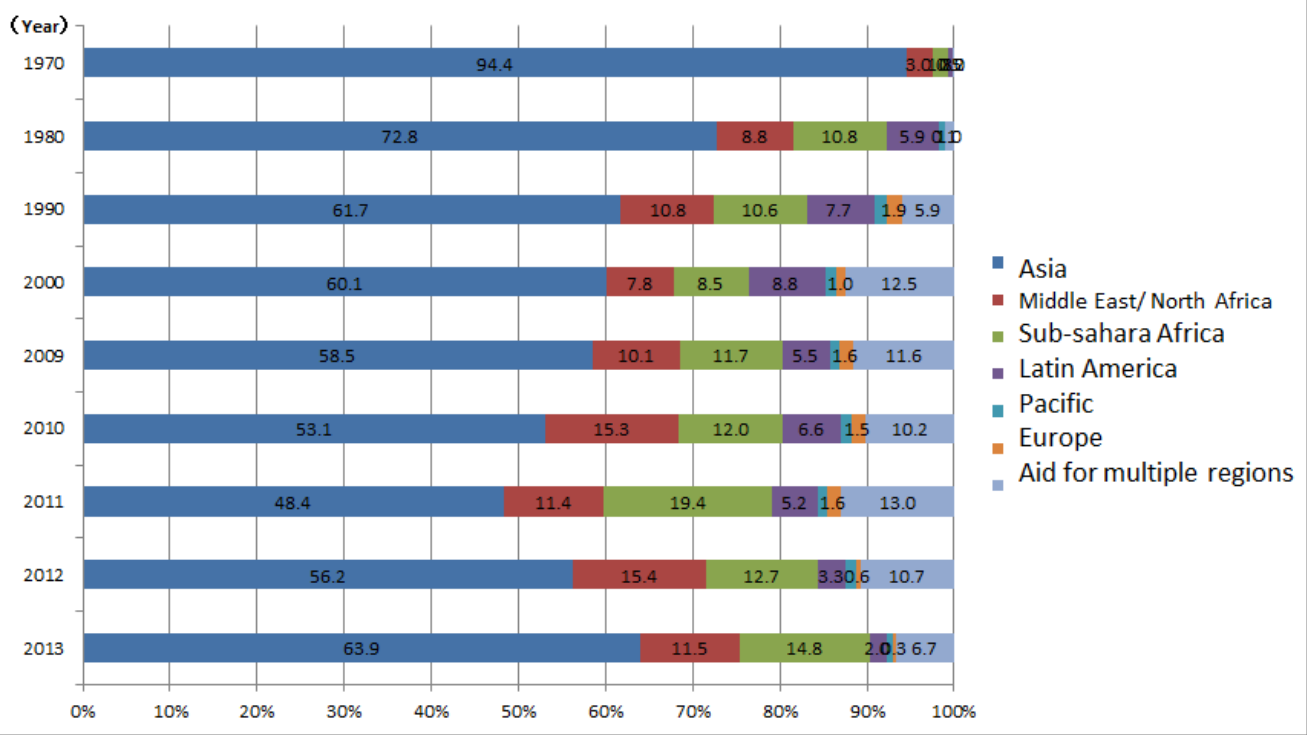

(Source: Ministry of Foreign Affairs, 2015) 
discuss or pledge any specific aid programs. In reality, however, the speeches of the Prime Ministers in the past TICADs always suggested increased ODA from Japan to Africa. The early 1990s was also a time when the international community had lost momentum for aid to Africa. With the end of the Cold War, both Western countries and the former Soviet Union lost motivation to aid Africa militarily and politically. Japan saw this vacuum as a potential way to exercise its influence in the welfare of the world, and committed itself to organising TICAD to boost aid to Africa.

Between TICAD III (2003) and IV (2008), Japanese ODA to Africa quadrupled, and the share of Africa in total amount of ODA increased from less than 9 per cent to close to 12 per cent (Figure 1). This sharp increase was not only the result of a domestic drive in Japan, but was largely a response to the global initiative to give a "big push" to enable the economic and social development of African countries to take off. Japanese ODA to Africa sharply increased after the Gleneagles Summit in 2005, at which the United Kingdom (U.K.) government, the chair, strongly advocated bringing aid to Africa to the forefront of the debate. Meanwhile, trade between Japan and African nations had been constantly increasing. Japan-Africa trade rose at an annual rate of 18.8 per cent between 2002 and 2007, and in 2006 Japanese FDI to Africa stood at US\$ 889 million (Ministry of Finance, 2009; see also Lumumba-Kasongo, 2010).

While Japanese trade with Africa increased, its pace of expansion was much slower than China. China's trade was about the same size as Japan at the beginning of the 2000s, but increased by 10 times in 10 years (Figure 2). China also launched a forum to discuss African development called the Forum on China-Africa Co-operation (FOCAC) in 2000. When Japan started TICAD in 1993, there was no major Asian donors involved in the discourse on aid to Africa. However, in the last decade, there has been a growing sense of threat among Japanese ODA officials and private companies that unless Japan makes unambiguous steps toward promoting trade with the vast African market and strengthening bi-lateral diplomatic relationships with African states, its appeal as a strong non-western partner will be lost to China. Such changes in international contexts also coincided with domestic pressure to allocate more resources to domestic matters and to be more accountable to tax payers. The 
AFRICAN

EAST-ASIAN

AFFAIRS

total amount of ODA has shown a gradual decrease in the last several years, while the share of aid to Africa has been slightly increasing. Therefore, unlike the 1990s or early 2000s, when there were stronger drives for humanitarian aid and contribution to Millennium Development Goals, in recent years the emphasis of the Japanese government tends to be skewed toward more pragmatic interests in diplomacy and trade.

\section{Figure 2: Trend of import in Africa by the country of origin}

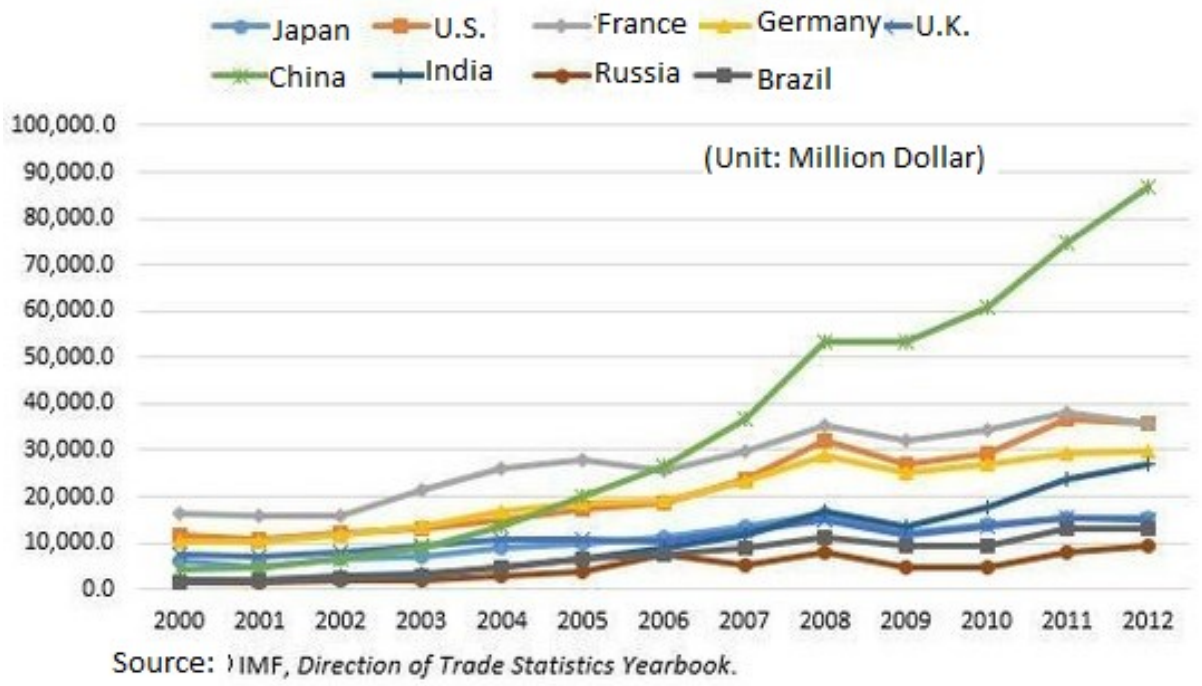

(Source: IMF, Direction of Trade Statistic Yearbook)

\section{TICAD processes: a multiplicity of interests}

As Table 1 shows, the first TICAD in 1993 highlighted the inter-regional cooperation between Asia and Africa. Along this line, there arose active discussion about the potential of Japanese developmental model to be transferred to Africa. As I will discuss later, this is one of the major drives behind the discourse on aid to Africa throughout the TICAD process. The emphasis on humanitarianism and aid for social 
development is visible in the earlier TICADs, while, in the recent two TICADs (TICAD IV and V), the focus is growingly shifting to economic growth, infrastructure building, and trade.

In this section, I will shed light on the diverse interests negotiated in the planning process toward TICAD IV and V.

TICAD IV in 2008 was a success in terms of the number of people mobilised. Representatives of 51 African countries, donors, Asian countries, and 50 NGOs participated. Three thousand people attended, excluding those who came to the side events. After five years, TICAD V had still more participants: representatives of 51 African countries, 31 donors and Asian countries, and 72 from international and

\begin{tabular}{|l|l|}
\hline \multicolumn{2}{|l|}{ Table 1: Major themes of respective TICAD } \\
\hline $\begin{array}{l}\text { TICAD I } \\
(1993)\end{array}$ & $\begin{array}{l}\text { Transfer of Asian development experiences to Africa } \\
\text { Aid for political and economic improvement } \\
\text { Education/ training } \\
\text { Environmental friendliness } \\
\text { Partnership and co-operation }\end{array}$ \\
\hline $\begin{array}{l}\text { TICAD II } \\
(1998)\end{array}$ & $\begin{array}{l}\text { Improved development planning and good governance } \\
\text { Conflict prevention }\end{array}$ \\
\hline $\begin{array}{l}\text { TICAD } \\
\text { III }\end{array}$ & African ownership and international partnership \\
\hline $\begin{array}{l}\text { TICAD } \\
\text { IV (2008) }\end{array}$ & $\begin{array}{l}\text { Japanese political will and action plan for support for African } \\
\text { development } \\
\text { Doubled ODA and FDI to Africa }\end{array}$ \\
\hline $\begin{array}{l}\text { TICAD } \\
\text { V (2013) }\end{array}$ & $\begin{array}{l}\text { Transformation for quality growth } \\
\text { Boosting economic growth with infrastructure development } \\
\text { Empowering Farmers } \\
\text { Promoting sustainable and resilient growth } \\
\text { (Source: Aoki, 2013:2-3) }\end{array}$ \\
\hline
\end{tabular}




\section{AFRICAN \\ EAST-ASIAN \\ AFFAIRS

regional organisations. The total number of participants was as many as 4,500. At the end of each TICAD, a declaration of commitment has been announced. In the case of TICAD V in 2013, the Yokohama Declaration stated three pillars of assistance; (1) peace and security, (2) powerful and sustainable economic growth, and (3) an inclusive society, and announced the target of ODA to achieve them as US\$ 3.2 billion over 5 years. Compared to TICAD IV, the emphasis was more clearly on economic infrastructure building and industrial human resource development. Japanese Prime Minister Abe also announced a new program called the African Business Education (ABE) Initiative, under which 1,000 African youths will be provided scholarships to pursue graduate-level degrees in Japanese universities. While there is growing influence from business sector to promote the Public-Private Partnership model of ODA to enhance investments and trade in Africa, there are various other actors involved in the TICAD processes and the discourse on aid for Africa.

Actors involved in the discourse on aid for Africa and their modes of participation

In terms of ODA and TICAD processes, the Ministry of Foreign Affairs (MOFA) is in charge of setting the agenda and overall management. Of course, one ministry alone cannot plan TICAD because it has various diplomatic and financial implications and is also related to ODA implementation in Africa. Therefore, the interests of other ministries, such as the Ministry of Finance, and of ODA implementing agencies such as JICA (the Japan International Co-operation Agency), are also reflected. In addition, since TICAD is co-organised by the Japanese government, the United Nations via the Office of the Special Advisor on Africa, UNDP (United Nations Development Program), and the World Bank, these parties are supposed to coordinate and plan together (Kidera, 2008). Furthermore, given the international trend to foster the initiatives of aid-recipient countries, partnership with and ownership of the African governments in the development process has been among the principles of TICAD since its second meeting in 1998. The representatives of African embassies argued that the Japanese government must hear their voices in planning TICAD (Mtango, 2008). Moreover, as discussed earlier, 
civil society organisations have become more and more active. Although MOFA was in the position of co-ordinating these different stakeholders and building consensus on the principles and contents of TICADs, in reality, as some of the anonymous interviewees from the embassies and civil society organisations pointed out, the messages from MOFA were lacking in consistency and clarity. This was partly because MOFA did not have a permanent office for TICAD. Each time TICAD was held, different officials were involved, and there was little effort to maintain the records and experience of earlier TICADs, which made the current person in charge start the process from scratch all over again.

Until the time of TICAD IV, there was a civil society organisation named the TICAD Civil Society Forum (TCSF), which ceased operation in March 2009. The TCSF was established in 2004, after TICAD III in 2003, and it was to focus its activities on influencing the TICAD IV process. According to Minoru Obayashi (2008), after TICAD III Japanese civil society organisations were criticised by their African counterparts for not playing enough of a role in advocating their perspectives in the TICAD. Without a permanent platform for co-ordinating the voices of civil society both in Japan and Africa, the influence on a conference like TICAD would be limited (Obayashi, 2008). At the earlier TICADs, civil society organisations sent representatives and made some appeals. However, such efforts were only made around the time of TICADs and there was little in the way of accumulated studies or systematic advocacy. Therefore, based on bitter experience and criticism from the African partners, after TICAD III, TCSF published the "Africa Policy Civil Society White Paper" annually until 2008, which evaluated Japanese ODA to Africa and made policy proposals (Obayashi and Ishida, 2005, 2006, 2007, and 2008). TCSF also made various efforts to raise public awareness and strengthen ties with the African embassies. A large part of the role of co-ordination among different kinds of stakeholders, raising public awareness, and leveraging the agenda-setting by MOFA, in which TCSF played a role until TICAD IV, were lost after its termination. Partly because of that, the advocacy from civil society was less vocal in the TICAD V process. Instead, the influence from the Keidanren, the Japan Business Federation, and other private sector entities has grown. 


\section{AFRICAN \\ EAST-ASIAN \\ AFFAIRS

Another significant group of stakeholders in TICAD process is, needless to say, African governments. There is a group called the African Diplomatic Corps (ADC) in which all 35 African embassies in Japan participate. ADC has had monthly meetings with MOFA as a channel of collective diplomacy (ADC 2010). In 2007, ADC organised a TICAD Committee whose chairperson was the then-ambassador of Zimbabwe. The ambassador had worked in the World Bank and was knowledgeable about development co-operation and the language of discourse in that field. It was also partly at the urging of TCSF to work collaboratively to put pressure on the government.

There was yet another group of people who were intellectual "advisors" to the government. The membership of this category largely overlaps with that of civil society organisations. Some academics and vocal development workers took on roles to influence the TICAD process as commentators for the government, seminar panellists, interviewees, authors of articles, or members of advocacy NGOs.

There was no full consensus in any of the groups that participated in the discourse on TICAD. At the same time, in the effort to clarify their messages, civil society organisations, African diplomats, academics, and business sector representatives merged their opinions into a few major arguments. In the following section, some of the major issues raised by the stakeholders and made mainstream in the TICAD discourse will be reviewed. The issues reflect different perspectives on development in Africa and the role of TICAD in it. Such differences of perspective cut across the groups of stakeholders mentioned above. There were differences within civil society and among African diplomats and academics, even though they had prepared written proposals and reports unanimously.

\section{Diversity of development ideas and interests brought to the scene}

\section{TICAD as a diplomatic tool}

While TICAD is supposed to be a multi-lateral, norm-setting forum, the Japanese government has always been tempted to use it as a diplomatic tool to demonstrate its commitment to global welfare and African development. In fact, if it was truly 
multinational, Japan could have simply provided the funds to organise TICADs to the UN or any multinational body and pushed forward its agenda indirectly. However, what the Japanese government has done is to put itself in the front while hesitating to make its stance clear. Being a multinational forum for norm-setting, TICADs have not pledged any bi-lateral aid to African countries, although the Japanese government has announced a rough target amount of ODA to be provided to Africa in the next few years. This has created a mismatch between the expectations from and impressions of the international community, especially African nations, and the Japanese official position on TICADs.

Diplomatically, as much as it was for Africa, TICAD was also to demonstrate the Japanese presence to the G8 and the donor community. In particular, TICAD IV coincided with Japan's turn to host the G8 Summit, which was held in Hokkaido a month after TICAD IV in early July. Therefore, unlike the three earlier TICADs, special diplomatic value was attached to TICAD IV. The principle of environment and climate change in the TICAD Yokohama Declaration was a telling example of the usage of TICAD IV. In the TICAD planning process, there were few people who discussed the details of this principle. Of course, there are a growing number of specialists on environmental issues in Japan, but most of them did not put themselves in the TICAD discourse. This principle was, rather, a message directed to the G8 and industrialised countries, not necessarily to Africa, because the environment was one of the major themes of the Hokkaido G8 Summit. Aside from the stabilisation of the global economy and development in Africa, the Hokkaido Declaration included reducing CO2 emissions by half by 2050 (Government of Japan, 2008).

The growing rivalry with emerging Asian powers, especially China and India, was another diplomatic driver. These emerging donor countries have increased their presence in Africa rapidly in the last few years. China started the FOCAC in 2000, and the most recent forum held in 2012was the third. It was attended by national representatives of 50 African countries (Forum on China-Africa Co-operation, 2012). Some TICAD organisers claimed that Japan was more successful than China. However, some Japanese observers saw that the FOCACs, which were accompanied by various commercial talks and bi-lateral meetings to contract actual aid programs, 


\section{AFRICAN \\ EAST-ASIAN \\ AFFAIRS \\ THE CHINA MONITOR}

sent clearer messages to and gained support from African countries (Takahashi, 2008). While there has been extensive criticism that the Japanese government failed to attract the attention of African governments, diplomatically, aid to Africa has also been considered as a way to get support from African countries in the international forum. For example, in 2005, when the U.N. Security Council was reformed, the Japanese government pledged an increase in ODA to many African countries so that these countries would vote for Japan to get a permanent seat on the Security Council. Regardless of its economic power, and having been defeated in World War Two, Japan has never been a permanent member of the U.N. Security Council, although this has been a long-cherished hope of consecutive governments in Japan. There were some African diplomats who hinted that there was a competition between the Japanese and Chinese governments to "buy" the votes of African governments to either support or reject a permanent seat for Japan. It is also possible that African governments used their relationships to the two rivalling donors in front of each other as a means of negotiation. In any event, TICAD is as important for Japan to show its presence to African governments as it is to show it to international society.

\section{Development of Africa through trade and investment}

As some scholars have pointed out, regardless of the lack of historically-developed sense of relatedness between Japan and Africa, there has been trade relationship with South Africa, Nigeria, and some resource-rich countries of Africa from the 1970s (Ampiah 1997, Cornelisen 2004). In the 1990s when Japan started TICAD, the motive to demonstrate Japanese leadership in African development has surpassed that to promote trade. Therefore, in the earlier TICADs, the employed themes had more flavour of humanitarianism than economy. Still, there has always been the business sector interests at the undercurrent of the discourse.

In contrast to the diplomatic concern, the basis of which was narrowly confined to MOFA and researchers concerned with diplomacy, drives for supporting economic growth through trade and investment came from various groups. The business sector started playing a role in the TICAD III process, and became growingly proactive in the processes toward TICAD IV and V. They tried to gain the government's support 
to promote trade with, and investment in, Africa ${ }^{1}$. Given the economic growth in Africa in the first decade of the twenty-first century, foreign direct investment flowing into Africa has also grown steadily (Hirano, 2008). However, advocates for Japanese companies claimed that they could not proceed to Africa as quickly as their European and other Asian rivals because there was less support from the Japanese government. For companies to establish local factories and firms in Africa, they need favourable legal treatment, access to a workforce, materials, and markets, all of which require the official support of respective African governments. Such official support should be ensured through diplomatic channels (Sano, 2008; see also Miyaji, 2008). Also, Japanese companies have limited experience and information about conditions in Africa. Furthermore, the physical and cultural distance between Japan and Africa and political instability in some African states have made Japanese companies much more careful compared to investing in Asia (Yoshimura, 2008).

\section{Poverty reduction in Africa and the Millennium Development Goals (MDGs)}

Concerns about social equity and the MDGs were expressed mostly by civil society organisations and some of the implementing organisations such as JICA. The concern for equity and poverty reduction was also the most visible and appealing frame of reference in the eyes of the general public. Publications and newspaper articles were often accompanied by pictures of children who are smiling but in need of help for schooling, women who cannot feed babies because of hunger, and so on. "Africa needing assistance" is an image which has been created and repeatedly confirmed in aid campaigns and awareness-raising activities in the last few decades in Japan. Although such campaigns by civil society organisations have been conducted from time to time, the period around TICAD IV and V saw unprecedented scales of media coverage on issues about Africa, which contributed greatly to raising public awareness. The mass media coverage of TICAD and Africa-related topics could not have happened if the process was kept exclusively among a few bureaucrats and business sector organisations. At the same time, their advocacy for MDGs and poverty reduction in Africa tended to create a rather simple image of Africa as a poor, conflict-torn continent. It should also be pointed out here that commitment to the MDGs was not simply an appealing message for the public, but 


\section{AFRICAN \\ EAST-ASIAN \\ AFFAIRS

also considered as a way to demonstrate how serious the Japanese were in contributing to global welfare. There were academics like Motoki Takahashi who argued for the stronger link between the TICAD and the global discourse on poverty reduction and appealed for Japan to lead the international community in supporting the poorest of the world in Africa (Gaiko Forum, 2008).

JICA has identified human security as one of its principle activities since former president Sadako Ogata assumed office in 2003. Ogata has been one of the proponents of this idea of human security since she was the U.N. High Commissioner for Refugees (for example, Sen and Ogata, 2003). Human security is a wide concept and translated into practice in various ways. At its very core, it means protecting people from threats to their survival, dignity, and livelihood. In JICA's operations, this philosophy is often realised in the form of social service projects and programs for the disadvantaged. Social service projects implemented in the name of human security by JICA have also been presented as activities which contribute to achieving the MDGs because they minimise the risks of the disadvantaged and prepare conditions that lead to safe and healthy lives (Mine, 2007).

In the end, JICA pursued two directions under the framework of TICAD. On one hand, there were efforts to highlight poverty reduction and the redistribution of wealth. On the other hand, aid for economic growth was pushed forward. At TICAD IV, JICA organised a symposium on public-private partnership and economic growth, and Ogata chaired the session. However, given its historically accumulated experience of field-based technical co-operation and the principle of human security, JICA did not completely shift to trade promotion.

\section{Transfer of Asian experience to Africa}

In the TICAD planning process, there was much discussion about transferring Asian experience to Africa. Despite frequent references to it, there was no clear definition of what people meant when they talked about Asian models which were worth transplanting to Africa. The vague consensus would be that an Asian model is a public-private co-operation in development assistance, in which a package of infrastructure building and industrial skills training provided by Japanese ODA 
would encourage investment by private companies (mostly Japanese) and contribute to enhancing the foreign trade of the developing countries assisted by Japan. Shozo Kitta mentioned in a roundtable talk that in Asia, governments played active roles in the process of economic development, which was different from the neo-liberal economic theory dominant in the World Bank and some other aid agencies (International Development Journal 2008:20). In the same roundtable, however, Izumi Ohno shared her view that Asian development was achieved through a combination of rural development and industrialisation, which led to poverty reduction through economic growth. They were both talking about aspects of economic growth in Asia but somewhat differently. At the conclusion of the roundtable, three discussants - Kitta, Ohno, and Shinsuke Horiuchi—concluded that the creation of jobs would lead to economic growth, and vice versa; and such cycles of stable growth would lead to good governance. What was unique to Japan in its ODA and Asian experience was its prioritisation of job creation and nationbuilding ${ }^{3}$. In the same issue of the International Development Journal in May 2008, the month TICAD IV was held, there were many other opinions about the transferable Asian model, such as industrial clusters (Sonobe, 2008) and the "One Village One Product" movement (Yoshida, 2008).

There is a widespread belief among Japanese government officials that Japanese aid supported Asian countries to achieve miraculous economic development in the 1970s and 1980s. Also, Japan itself has had the experience of achieving rapid industrialisation, rising from the ashes after World War Two. These two experiences, successful foreign aid to Asian countries and Japan's own industrialisation, made many people claim that Japan could extend its experiences for African countries to adopt. The aid model of public-private co-operation in Asia has often been referred to by people in the business sector to support their demands for flexible ODA which encourages Japanese companies' participation in aid projects (Keidanren 2007). At the same time, this can be seen as a struggle on the part of the Japanese government to demonstrate the comparative advantage of Japanese aid over that of European donors, which have longer historical relationships with Africa, however controversial their histories may be. At the same time, it has been a several decades 


\section{AFRICAN \\ EAST-ASIAN \\ AFFAIRS \\ THE CHINA MONITOR}

since Japan achieved economic development from the 1950s to 1970s and the economic and political environments surrounding developing countries in Africa now are quite different from when Japan was in their position. Therefore, according to some analysts, what Japan itself can offer is less attractive than the first-hand experience of economic growth which emerging Asian donors such as China, India, or Korea can offer.

Still, African leaders were very keen on learning from the development experiences of Asian countries. Policy advice by former Malaysian government officials to Zambia and Japanese university professors' advisory service to the Ethiopian Prime Minister's Office were both activities funded by JICA but started with inquiries and initiatives from African governments. The sharing of experience between developing countries - so-called South-South Co-operation - has been mentioned repeatedly in the TICAD discourse as a mechanism that would be effective in transferring Asian experience to Africa. Japan has long been the promoter of South-South Cooperation, but its high potential for aid to Africa was reemphasised in the TICAD process. Atsushi Hanatani reviewed the history of research on transferring Asian experience to Africa in Japan, which recurred as TICADs have been held since 1993. As a JICA staff member who led the study group on Asian economic growth and its implications for African development before TICAD IV, he listed the issues to be considered, avoiding giving any particular definition of the idea of transfer. The points he promoted were: (1) to understand African needs before talking about Asian development models and experiences which are transferrable; (2) to foster mutual learning between Asia and Africa; (3) to relate Asian experiences with positive aspects of the conditions in Africa, instead of pointing out things that are lacking; and (4) to provide various cases, both positive and negative, of Asian experience, from which Africans can extract lessons subjectively (Hanatani, 2008:6-7).

\section{Japan and Africa after TICAD V}

The world economy has experienced a great crisis since TICAD IV was held in May 2008. Even the car manufacturing companies which have been the engines of economic growth in Japan experienced a serious decrease in profits, and have closed 
down factories and fired a large number of employees until it started to recover in 2013. The tax revenue of the Japanese government greatly decreased in FY2009, while expenditure to rescue moribund financial bodies, industries, and workers is enormous. In addition, in March 2011, the largest earthquake in the history of Japanese scientific quake observation and the tsunami following it hit north-Eastern Japan. They caused a massive loss of life and displacement of people. Given the acute domestic problems, the government has faced difficulties sparing a large sum of revenue for international ODA, which does not have demonstrable and immediate benefit for Japanese society and its constituents.

Under the initiative of the current government, which took power in 2012, the Japanese economy looks to be recovering from two decades of stagnation. In 2014 and 2015, major export-oriented companies have renewed their record of annual sales, although the picture is mixed among companies of different industrial sectors. This revitalisation of export-oriented companies and continued budgetary restraints resulted in the marginalisation of the appeals for Japan to play the conventional role of a donor nation. In contrast to the period when Japan tried to detach ODA from national interests and to improve its moral status as a humanitarian contributor to international welfare, it is now finding new roles of ODA, making it beneficial for people both in developing countries as well as in Japan.

In February 2015 the cabinet adopted a new ODA Charter, building on the report of the Expert Council and reflecting the result of public consultation. The Charter sets the fundamental principles and framework of Japanese ODA, including that to Africa. It was first decided in 1993, the same year TICAD started, and went through some minor revisions in 2003. The subject of much debate, the current Charter, renamed the Development Co-operation Charter, includes emphasis on trade promotion, co-operation (particularly economic) through non-ODA channels, and proactive support to peacekeeping operations. While continuing to highlight Japan's roles in humanitarian assistance and poverty reduction, relative weight to humanitarian and social development is lessened in this enlarged scope. Rather, the emphasis is more on economic aspects of development which are mutually beneficial for the recipient countries and Japan. In this context, the direct reference to social 


\section{AFRICAN \\ EAST-ASIAN \\ AFFAIRS

services such as education and health is kept minimal, except for the industrial human resource development which is closely linked with economic co-operation.

Many critics point out that there is a drive for protecting Japanese comparative advantage in the international development scene behind the revision of the ODA Charter. On one hand, the rise of China, which seems open in its national interests and militarist goals for territorial expansion, intimidates the Japanese government (Asahi Shinbun, 2015). Before it loses the ground it holds now, Japan should also allow itself to use ODA for its diplomatic interests and the promotion of exports and investments by Japanese private companies. This is a characteristic attitude of the current Abe government of the Liberal Democratic Party. At the same time, the fact that Abe was re-elected with a great majority of support indicates that, after two decades of stagnation, Japanese constituents are tired of policy measures which do not promote the immediate improvement of their economic and living conditions, and it is more difficult to get their support for ODA programs which aim to contribute to noble but distant causes.

Japanese ODA to Africa is changing from large-scale projects whose cost has been fully covered by Japan to ones that facilitate and catalyse the developmental process based on its accumulated experience of field-oriented aid programs since the 1990s. The well-planned and devoted practices of Japanese experts on the ground reflect the Japanese manufacturing spirit that excellence should reside in the details. The experience of such careful operation of aid programs will be a valuable contribution in itself, which is worth sharing with African counterparts. There are also schemes to adapt the advanced technologies in engineering and agriculture available in Japanese universities and corporate laboratories for development in Africa. While Japanese aid to Africa will likely be sustained at the current level, the focus is likely to shift more toward pragmatic partnerships between African states and Japan economically and diplomatically. However, it is ironic to see that the pendulum is swinging back, after decades of great effort to reorient Japanese ODA away from being closely linked with national economic interests to be more detached and humanitarian in its focus. 


\section{Endnotes}

1. Nippon Keidanren (the Japan Business Federation) dispatched an Economic Research Mission to Africa in October 2007 and came up with a set of recommendations. One of the main messages was to establish stronger publicprivate partnerships. The public-private partnerships in this case include (1) supplementing projects by private firms with ODA (loans) to promote investment in Africa; (2) enhanced flexibility of ODA grant projects to encourage Japanese private companies to participate in the bidding; and (3) relaxed criteria of eligibility for Japanese ODA loans. Nippon Keidanren also requested coordination among ministries and governmental bodies so that the government would be more effective and efficient in its promotion of trade in Africa. It was also hoped that industrial human resource development (the skills training of African workers) would be enhanced by means of Japanese ODA (Keidanren, 2007).

2. Such barriers are sometimes called "Africa risk" and call for more governmental support for private sector investment (Ohno, 2007).

3. JICA also organised a study group on Asian economic growth and its implications for African development. The report of this study group (JICA, 2008) became the basis of the symposium organised by JICA as one of the TICAD events, whose title was "African development and Asian experience of growth: The roles of the government and private sector for sustainable economic growth in Africa".

\section{Bibliography}

ADC (African Diplomatic Corps). 2010. Organizational website [Online]. Available: http://www.adc-japan.org/en/ [2010, March 5].

Ampiah, K. 1997. The Dynamics of Japan's Relations with Africa: South Africa, Tanzania and Nigeria. London: Routledge. 
AFRICAN

Aoki, K. 2013. Japan and the TICAD Process. Policy Briefing 66, Global Powers and Africa Programme, 4.

Asahi Shinbun. 2015. Kaihatsu Kyoryoku Taiko: Gaiko no Henshitsu wo Osoreru [Development Co-operation Charter: Fear of the Character Change of Diplomacy]. Asahi Shinbun [Asahi Newspaper] February 11.

Cornelissen, S. 2004. Japan-Africa Relations: Patterns and Prospects, in Taylor, I., and Williams, P., (eds.). Africa in International Politics: External Involvement on the Continent. London: Routledge. 116-135.

Forum on China-Africa Co-operation. 2012. Forum website [Online]. Available: http://www.focac.org/eng/ [2015, May 20].

Gaiko Forum. 2008. Chunichi taishi San-nin ga kataru TICAD IV [TICAD IV seen from the eyes of three ambassadors in Japan], interview with Mtango, E.E.E. (Ambassador of Tanzania), Simasiku, S. (Ambassador of Zambia), and Rwamasirabo, E. (Ambassador of Rwanda), Gaiko Forum, 6:24-28.

Government of Japan. 2008. G8 Hokkaido Toyako Summit Leaders Declaration [Online]. Available:http://www.mofa.go.jp/mofaj/press/pr/pub/pamph/pdfs/ summit_08_08.pdf [2015, May 25].

Hanatani, A. 2008. Ajia no kaihatsu keiken to afurika: TICAD IV ni muketa JICA/ JBIC no seisakuteigen kentou purosesu nit suite [Asian Development Experience and Africa: The process of policy proposal in JICA and JBIC toward TICAD IV], Kokusai Kyoryoku Kenkyu [Studies on International Cooperation], 24, 1: 1-9.

Hirano, K. 2008. Ima koso Afurika ni hitsuyou na minkan toshi: Genchi de motomerareru nihon no kakawari toha [Time for private investment in Africa now: The Japanese commitment required there, International Development Journal, 1: 16-17.

International Development Journal. May 2008. "Roundtable: The meanings of 'Asian experience to Africa'”, International Development Journal: 20-23. 
AFFAIRS

International Monetary Fund. 2014. Direction of Trade Statistical Yearbook. Washington, D.C.

Japan International Co-operation Agency. May 2008. Report of the Examining groups on African Development and Asian Economic Growth [Online]. Available:

http://www.jica.or.id/jica-ri/publication/archives/jica/field/200805_aid.html [2010, March].

Keidanren. 2007. Opinions regarding development in Sub-Saharan Africa. Unpublished report.

Kidera, M. 2008. Interview with Masato Kidera, Director-General for Sub-Saharan African Affairs. Africa, 48(3):8-13.

Lumumba-Kasongo, T. 2010. Japan-Africa Relations. London: Palgrave MacMillan.

Ministry of Finance. Trade statistics of Japan [Online]. Available:

http://www.customs.go.jp/toukei/info/index.htm

[2009, April].

Mine, Y. 2007. Response to the questionnaire, Congress of Informed People on International Co-operation (Kokusai Kyoryoku ni Kansuru Yushikisha Kaigi) [Online]. Available:

http://www.mofa.go.jp/mofaj/gaiko/oda/seisaku/yushikisya.html

Ministry of Foreign Affairs, Japan. 2015. ODA White Paper 2014. Tokyo: Ministry of Foreign Affairs.

Miyaji, M. 2008. Ima koso Kanmingaku ga ittai to natte afurika he: kakkoku no chamu wo ikashita keizai seichou shien wo [To Africa by uniting public, private, and academia now: Support for economic growth based on the strength of each African country]. International Development Journal, 1:20-21.

Mtango, E.E.E. 2008. TICAD IV kaisai ni atatte [Japanese good deeds will circle 
AFRICAN

back to do them good in the long run]. Africa, 48(3):14-17.

Obayashi, M. 2008. Afurika seisaku shimin hakusho 2007 hakkou: Afurika kaihatsu kaigi heno senryakuteki teigen [Publication of the Africa Policy Civil Society White Paper 2007]. International Development Journal, April: 14-15.

Obayashi, M., and Ishida, Y. 2005, 2006, 2007, and 2008. Afurika seisaku shimin hakusho [Africa Policy Civil Society White Paper]. Tokyo: Koyo Shobo.

Ohno, I. 2007. Stakeholders' Perspectives, Congress of Informed People on International Co-operation (Kokusai Kyoryoku ni Kansuru Yushikisha Kaigi) [Online]. Available: http://www.mofa.go.jp/mofaj/gaiko/oda/seisaku/ yushikisya.html. [2010, March].

Sano, T. 2008. Nihon ha kanmin renkei de afurika ni deteiku shikanai: Kigyo no shinshutsu ni jyuyo na nikokukan no shinraikankei [Japan has to proceed to Africa through collaboration between public and private sectors: Trust between two countries indispensable for company investment], International Development Journal, 1: 21.

Sen, A., and Sadako, O. 2003. Human Security Now: Final Report of the Commission on Human Security. New York: Commission on Human Security.

Sonobe, T. 2008. Afurika sangyo hatten no daiippo [Industrial cluster: The first step for African industrial development], International Development Journal,24: $11-13$.

Takahashi, M. 2008. Sekai ha 'saiteihen no 10-okunin' wo sukueruka [Can the world save 'Bottom Billion7?], Gaiko Forum, 21(6):11-21.

Yoshida, E. 2008. Isson Ippin Undo ha afurika ni nedukunoka: Oita, tai soshite maraui no keiken [Will One Village One Product movement take roots in Africa?: Experiences in Oita, Thailand, and Malawi], International Development Journal, May: 27. 


\section{AFFAIRS}

Yoshimura, T. 2008. Afurika shien ni minkan no chikara wo ikase: Kanmin renkei no shinka niyoru atarashii moderu kouchiku wo [Utilize private sector capacities for aid to Africa: Toward the establishment of a new model by deepening public-private cooperation], International Development Journal, 1: 20 . 